\title{
SISTEM PENDUKUNG KEPUTUSAN CERDAS KESESUAIAN LAHAN DENGAN JENIS TANAMAN PANGAN: STUDI KASUS KABUPATEN SIKKA
}

\section{INTELLIGENT DECISION SUPPORT SYSTEM FOR FOOD PLANT LAND SUITABILITY: CASE STUDY IN SIKKA DISTRICT}

\author{
Yanter Wilve Baly Woda ${ }^{1)^{*}}$, Irman Hermadi' ${ }^{2)}$, dan Marimin ${ }^{3)}$ \\ ${ }^{1)}$ Program Studi Teknik Informatika, Fakultas Teknik, Universitas Nusa Nipa \\ Jln. Kesehatan No.3, Maumere 86111- Nusa Tenggara Timur \\ Email: yanterwoda@gmail.com \\ ${ }^{2}$ Departemen Ilmu Komputer, Fakultas Matematika dan IPA, Institut Pertanian Bogor \\ ${ }^{3)}$ Departemen Teknologi Industri Pertanian, Fakultas Teknologi Pertanian, Institut Pertanian Bogor \\ Makalah: Diterima 18 September 2018; Diperbaiki 2 Februari 2019; Disetujui 20 Maret 2019
}

\begin{abstract}
Sikka District is an area with a dry tropical climate. Most of the plants especially food crops in Sikka District depend on rainfall. The lack of rain coupled with the weather anomalies occurring in Sikka District make Sikka District categorised in the area threatened by food insecurity. Food crop cultivation often experiences obstacles, one of which is in determining the suitability of agricultural land for the advancement of certain food crops because the productivity of food crops depends on the quality of the area used. Therefore, this study aimed to develop a smart decision support system to determine land suitability with food crops. This study used a fuzzy analytic hierarchy process to determine the value of alternatives based on parameters that affect the relevance of the land with the type of food crop. The results showed that corn food crops were the best alternative crop with a value of 0.339 of the three alternative food crops studied and then use the method fuzzy inference system to calculate the amount of land suitability. Kopong Village and Geliting Village were the best villages with land suitability values 81 .
\end{abstract}

Keywords: fuzzy analytic hierarchy process, fuzzy inference system, intelligent decision support systems, land suitability

\section{ABSTRAK}

Kabupaten Sikka merupakan daerah dengan iklim tropis kering, sebagian besar tanaman terutama tanaman pangan di Kabupaten Sikka bergantung pada curah hujan. Kurangnya curah hujan ditambah dengan adanya anomali cuaca yang terjadi di Kabupaten Sikka membuat Kabupaten Sikka masuk dalam daerah dengan ancaman rawanan pangan. Budidaya tanaman pangan sering mengalami kendala, salah satunya dalam menentukan kesesuaian lahan pertanian untuk budidaya tanaman pangan tertentu karena produktivitas tanaman pangan tergantung pada kualitas tanah yang digunakan. Oleh karena itu, penelitian ini bertujuan untuk mengembangkan sistem pendukung keputusan cerdas untuk menentukan kesesuaian lahan dengan jenis tanaman pangan. Penelitian ini menggunakan metode fuzzy analytic hierarchy proses (fuzzy AHP) untuk menentukan nilai dari alternatif berdasarkan parameter yang mempengaruhi kesesuaian lahan dengan jenis tanaman pangan tersebut maka diperoleh hasil bahwa tanaman pangan jagung merupakan alternatif tanaman pangan terbaik dengan nilai 0,339 dari tiga alternatif tanaman pangan yang dikaji dan kemudian menggunakan metode fuzzy inference system untuk menghitung nilai kesesuaian lahan maka diperoleh hasil bahwa Desa Kopong dan Desa Geliting merupakan desa terbaik dengan nilai kesesuaian lahan 81.

Kata kunci: fuzzy analytic hierarchy process, fuzzy inference system, sistem pendukung keputusan cerdas, kesesuaian lahan

\section{PENDAHULUAN}

Kabupaten Sikka merupakan salah satu kabupaten di Provinsi Nusa Tenggara Timur (NTT) yang termasuk dalam gugusan Pulau Flores. Total luas wilayah Kabupaten Sikka yaitu: $1731,92 \mathrm{Km}^{2}$ dengan penggunaan lahan didominasi oleh semak belukar dengan luas $17.323,86 \mathrm{Ha}$ atau $39,54 \%$ dari total luas wilayah Kabupaten Sikka (BPS, 2017). Kondisi iklim di Kabupaten Sikka yaitu beriklim tropis kering yang terdiri dari musim kemarau dan musim hujan. Dengan kondisi iklim tropis kering membuat sebagian besar tanaman khususnya tanaman pangan di daerah Kabupaten Sikka bergantung pada curah hujan. Minimnya curah hujan ditambah dengan adanya anomali cuaca yang terjadi di Kabupaten Sikka membuat Kabupaten Sikka masuk dalam daerah di Provinsi NTT dengan ancaman rawan pangan. Berbagai cara telah dilakukan pemerintah untuk mengatasi hal ini, namun belum memberikan hasil yang optimal. Hingga saat ini Indonesia masih melakukan impor bahan pangan dengan membebaskan bea masuk gandum dan kedelai yang secara tidak langsung malah menekan produksi pangan Indonesia sendiri (Insani et al., 2015). Kondisi cuaca merupakan hal 
penting yang perlu dipelajari karena cuaca di suatu daerah menentukan rangkaian aktifitas manusia. Sebagai contoh, informasi iklim dan klasifikasinya banyak menjadi acuan untuk bidang pertanian, transportasi, dan pariwisata seperti: pelayaran, penerbangan, dan masa pola tanam (Navianti et al., 2012). Cuaca merupakan faktor penghambat utama dalam kecocokan lahan dan jenis tanaman, disamping faktor-faktor lainnya dikarenakan cuaca dapat berpengaruh terhadap tanah, tanaman dan terhadap hama penyakit tanaman (Taiyeb, 2017). Evaluasi lahan merupakan pendekatan atau cara yang digunakan untuk menilai potensi sumber daya lahan (Djaenuddin et al., 2011). Tanaman yang dapat tumbuh pada suatu lahan merupakan tanaman yang mampu beradaptasi dengan lingkungan sekitarnya, dikarenakan tidak semua jenis tanaman khususnya tanaman pangan dapat tumbuh di sembarang lahan, maka dibutuhkan suatu sistem pendukung keputusan (SPK) untuk menentukan kesesuaian lahan dengan jenis tanaman pangan.

SPK merupakan pendekatan secara sistematis dalam menentukan teknologi ilmiah yang tepat dalam mengambil keputusan, sedangkan sistem pendukung keputusan cerdas (SPKC) merupakan sistem berbasis komputer yang interaktif menggunakan data, model, dan pengetahuan kepakaran untuk mendukung keputusan-keputusan dalam organisasi untuk menyelesaikan masalah yang kompleks. Konsep program bantu pengambilan keputusan saat ini berkembang dengan pesat, banyak metode yang digunakan untuk membantu dalam mengambil keputusan khususnya yang berdasarkan beberapa alternatif. Dengan meniru cara berpikir manusia, logika fuzzy dianggap memungkinkan untuk penyelesaian masalah yang mengandung ketidakpastian dan mengingat bahwa cukup banyak data karakteristik lahan maka pengolahan data dapat menggunakan fuzzy inference system (FIS) (Sevani et al., 2009). Analytic hierarchy process (AHP) merupakan salah satu metode yang dapat digunakan dalam pengambilan keputusan dengan memperhatikan faktor-faktor persepsi, prefensi, pengalaman dan intuisi dengan teknik yang terstruktur yang digunakan untuk mengatur dan menganalisis keputusan yang kompleks (Aikhuele dan Turan, 2017). AHP menggabungkan penilaianpenilaian dan nilai-nilai pribadi ke dalam satu cara yang logis (Marimin dan Nurul, 2010). Hendra et al. (2014) meneliti sistem pendukung keputusan cerdas menggunakan pendekatan Fuzzy analytic hierarchy process (Fuzzy AHP). Pada penelitian ini menerapkan Fuzzy AHP untuk mendapatkan nilai prioritas alternatif tanaman pangan yang dikaji berdasarkan kriteria atau parameter yang mempengaruhi kesesuaian lahan dengan jenis tanaman pangan tersebut, dan menggunakan FIS untuk mendapatkan nilai kesesuaian lahan berdasarkan data lapangan. Hasil utama penelitian ini, diharapkan mampu membangun sebuah SPKC untuk pemilihan alternatif tanaman pangan yang terbaik dengan lahan yang sesuai di Kabupaten Sikka.

\section{METODE PENELITIAN}

\section{Parameter Pengetahuan}

Kesesuaian lahan untuk jenis tanaman pangan dipengaruhi oleh beberapa parameter. Sesuai dengan petunjuk pada buku petunjuk teknis evaluasi lahan untuk komoditas pertanian 2011 dan hasil wawancara pakar terdapat 16 parameter yang akan digunakan untuk menentukan kesesuaian lahan yang terdiri dari 12 parameter numerik dan 4 parameter kategori. Parameter numerik yaitu temperatur $\left({ }^{0} \mathrm{C}\right)$, curah hujan (mm), kelembaban (\%), pH, bahan kasar $(\%)$, kedalaman tanah (cm), KTK liat $(\mathrm{cmol})$, Corganik (\%), kejenuhan basa (\%), lereng (\%), singkapan batuan (\%) dan batuan permukaan (\%), sedangkan parameter kategori yaitu drainase, tekstur, bahaya erosi dan bahaya banjir.

\section{Data dan Sumber Data}

Penelitian ini membutuhkan data-data untuk perhitungan nilai dari parameter yang digunakan, serta untuk pemilihan alternatif tanaman pangan yang terbaik dengan lahan yang sesuai. Data yang digunakan dalam penelitian ini adalah sebagai berikut:

1. Data sekunder yaitu data yang diperoleh dari buku petunjuk teknis evaluasi lahan untuk komoditas pertanian 2011.

2. Data primer yaitu data yang didapat langsung dari para pakar dengan cara observasi, wawancara dan menggunakan alat ukur berupa kuesioner. Pakar pada penelitian ini berasal dari Institut Pertanian Bogor dan pakar dari Kabupaten Sikka.

\begin{abstract}
Alat
Peralatan yang dugunakan dalam penelitian ini terdiri atas kuesioner, XAMPP dan Sublime Text3. Penggunaan alat dan fungsinya dirinci pada Tabel 1.

\section{Pengembangan Sistem Pendukung Keputusan Cerdas (SPKC)}

SPKC merupakan sistem berbasis komputer yang interaktif menggunakan data, model, dan pengetahuan kepakaran untuk mendukung keputusan-keputusan dalam organisasi untuk menyelesaikan masalah yang komplek dengan menggabungkan teknik artificial intelligent. Menurut Wren et al. (2009) struktur sistem pendukung keputusan cerdas dapat digambarkan sebagai diagram input, proses dan output.

Penelitian ini mempunyai empat komponen utama SPKC yaitu sistem manajemen basis model, sistem manajemen basis data, sistem manajemen basis pengetahuan dan sistem manajemen dialog. Sistem ini dapat memudahkan komunikasi antara pengguna dengan komputer dan bersifat interaktif
\end{abstract}


(Fibrian et al., 2010). Stuktur model SPKC dapat yang dirancang dapat dilihat pada Gambar 2. dilihat pada Gambar 1 dan kerangka kerja SPKC

Tabel 1. Penggunaan alat dan fungsinya

\begin{tabular}{clcl}
\hline No & Nama Alat & Versi & Fungsi \\
\hline 1 & Kuesioner & - & Menggali sumber pengetahuan dari pakar \\
2 & XAMPP & 1.8 .1 & Pengembangan web berbasis PHP dan MySQL \\
3 & Sublime Text 3 & 1.0 .0 .1 & Text editor untuk menulis kode pemrograman \\
\hline
\end{tabular}

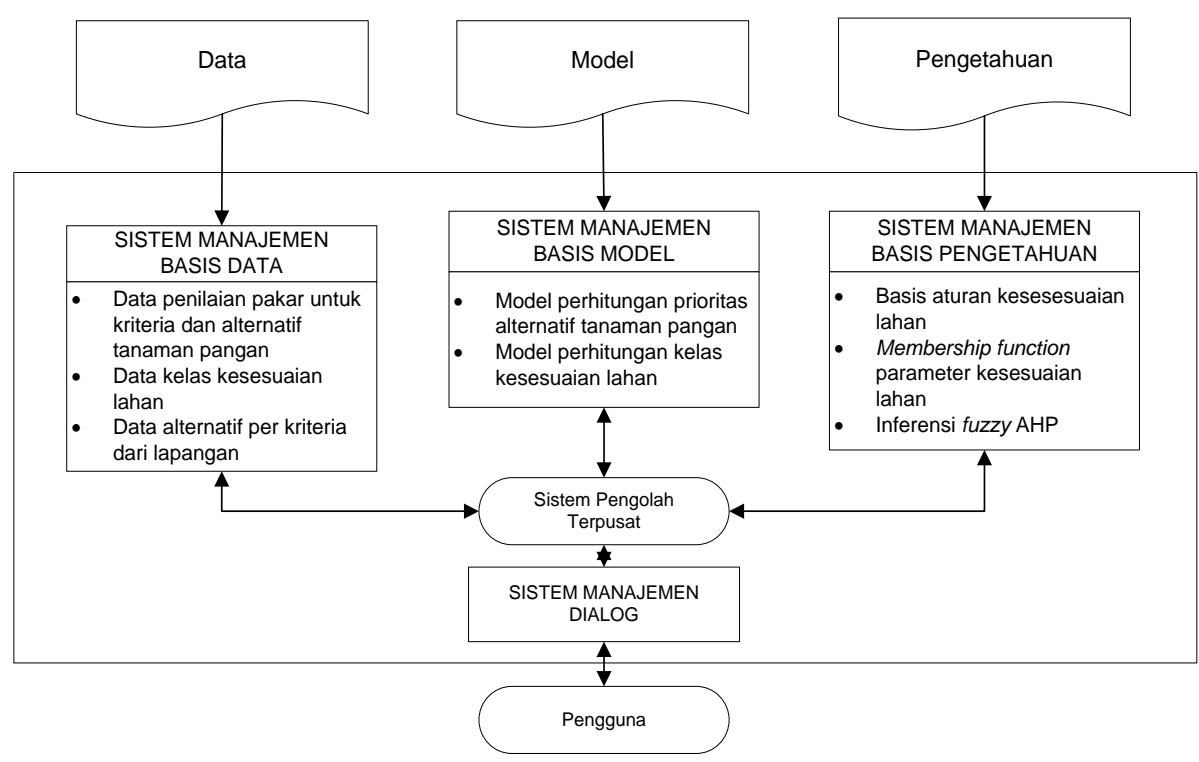

Gambar 1. Struktur model sistem pendukung keputusan cerdas kesesuaian lahan
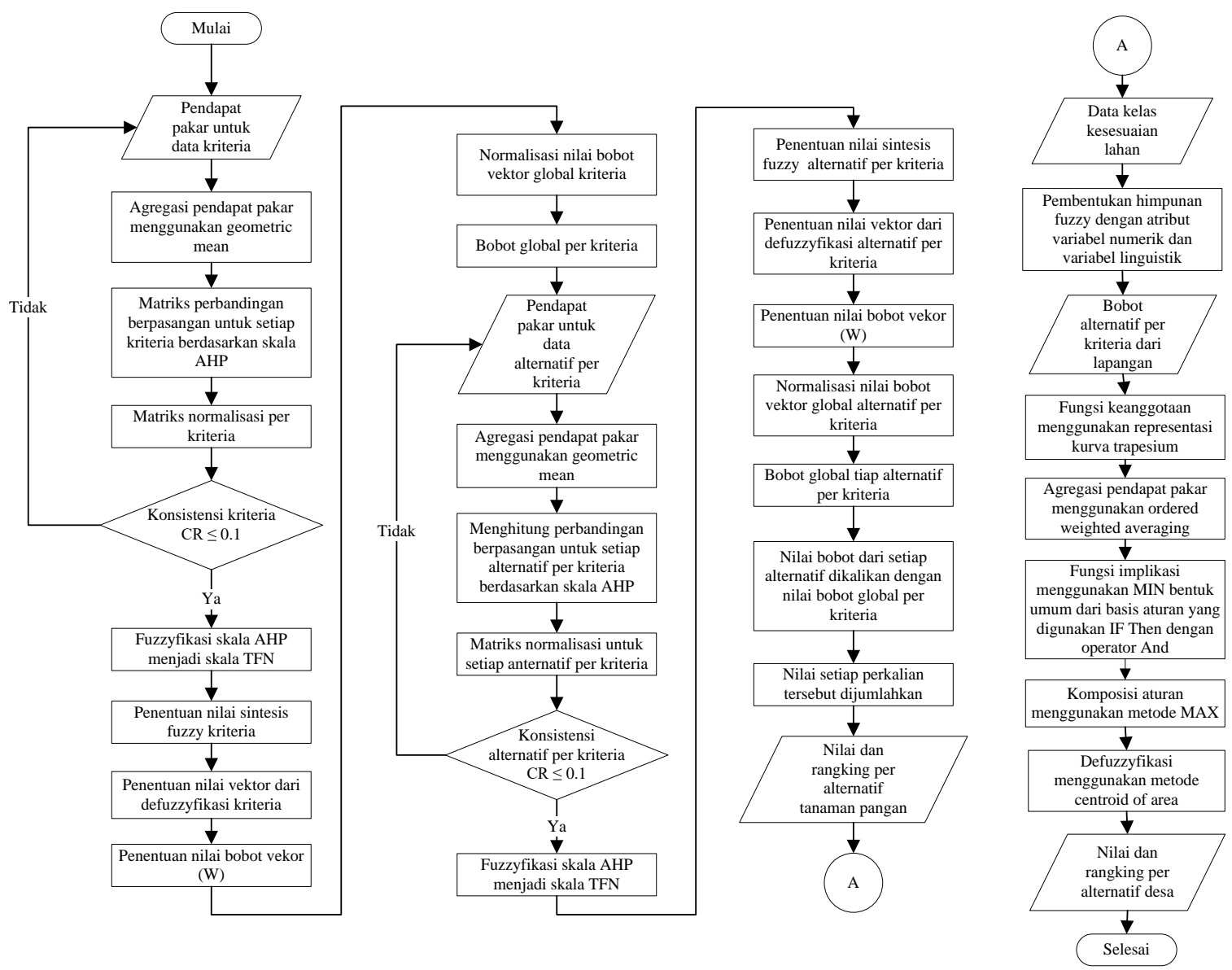

Gambar 2. Kerangka kerja sistem pendukung keputusan cerdas kesesuaian lahan 


\section{HASIL DAN PEMBAHASAN}

Secara umum hasil dan pembahasan penelitian ini terbagi atas dua bagian yaitu, hasil dari perhitungan model prioritas alternatif tanaman pangan menggunakan metode Fuzzy AHP dan model perhitungan kesesuaian lahan menggunakan metode FIS tipe Mamdani.

\section{Model Prioritas Alternatif Tanaman Pangan Menggunakan Fuzzy AHP}

Sesuai dengan petunjuk pada buku petunjuk teknis evaluasi lahan untuk komoditas pertanian 2011 dan hasil wawancara pakar, terdapat 16 parameter yang mempengarui kesesesuain lahan dengan lahan tanaman pangan khususnya tanaman pangan padi sawah tadah hujan, padi gogo dan jagung. Struktur hirarki kriteria kesusesuian lahan dapat dilihat pada Gambar 3.

\section{Perhitungan AHP Untuk Semua Kriteria}

Tahapan pertama perhitungan AHP yaitu melakukan perbandingan berpasangan untuk kriteria dengan cara membandingkan data antara kriteria dalam bentuk matriks berpasangan dengan menggunakan skala intensitas kepentingan AHP
(Marimin et al., 2017). Matriks perbandingan berpasangan antar kriteria berdasarkan inputan dari pakar, bisa dilihat pada Tabel 2 .

Setelah menentukan matriks dilanjutkan dengan menghitung matriks normalisasi, nilai inputan perbandingan matriks di atas kemudian diproses untuk mencari bobot vektor prioritas, consistency measure (CM), consistency index (CI), dan consistency ratio (CR). Matriks normalisasi dapat dilihat pada Tabel 3. Sebelum menghitung nilai bobot prioritas, setiap sel pada kolom matriks dibagi dengan jumlah kolom pada tiap selnya, misalkan untuk sel pertama:

$$
\mathrm{C} 1=\frac{1}{22,5}=0,044
$$

Kemudian menghitung nilai bobot prioritas yaitu dengan cara hasil pembagian sel yang telah diperoleh pada setiap baris matriks dijumlahkan, kemudian dibagi dengan banyaknya sel pada baris tersebut (banyak kriteria $=16$ ), misalkan untuk baris pertama:

$$
\begin{aligned}
\text { Bobot }= & {[(0,044+0,058+0,048+0,039+0,093+} \\
& 0,048+0,037+0,026+0,033+0,036+ \\
& 0,031+0,049+0,05+0,03+0,044+ \\
& 0,043) / 16]=0,044
\end{aligned}
$$

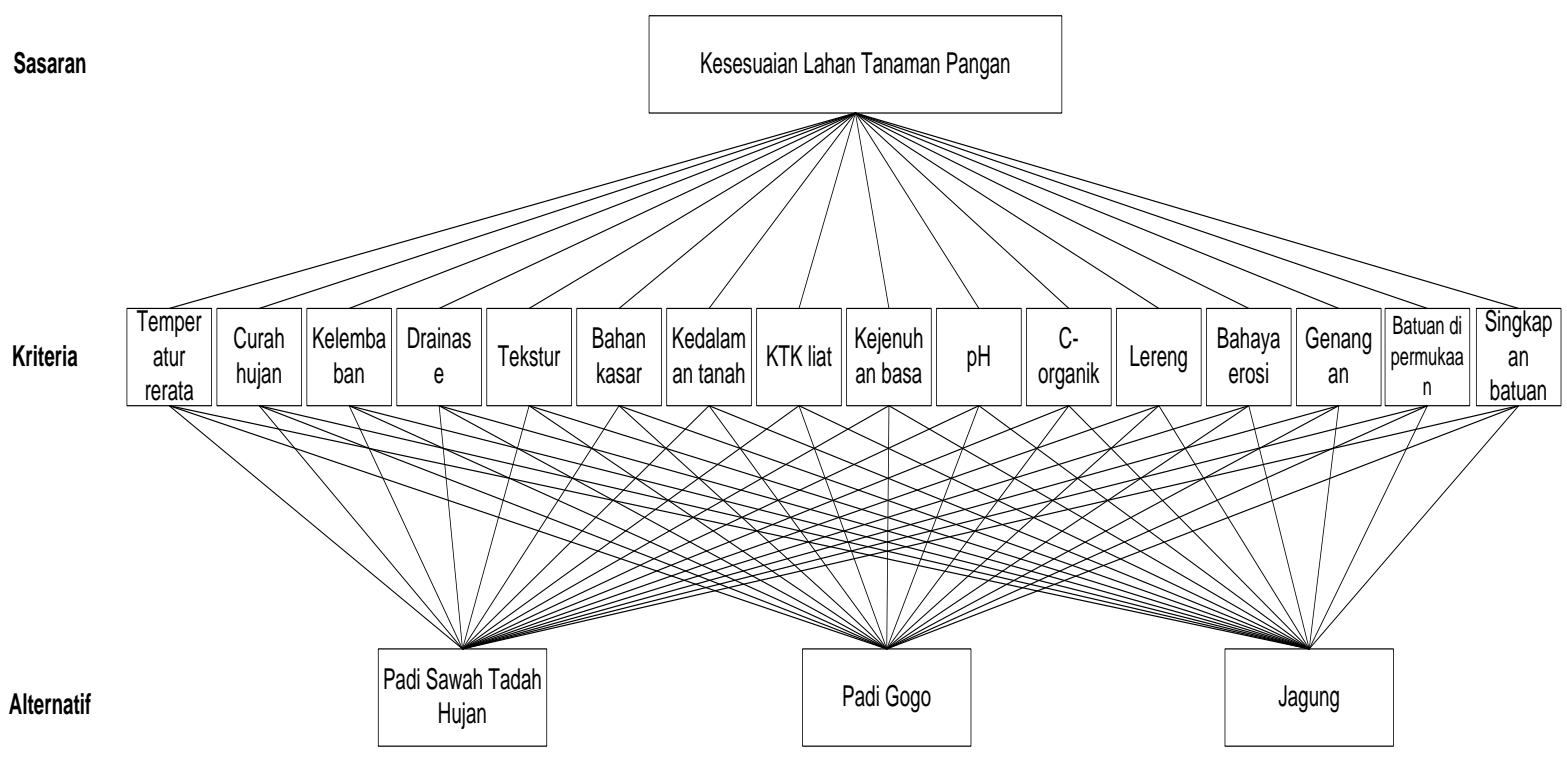

Gambar 3. Struktur hirarki kesesuaian lahan

Tabel 2. Matriks perbandingan AHP antar kriteria

\begin{tabular}{lccccccccc}
\hline Kode & C01 & C02 & C03 & $\ldots$ & C12 & C13 & C14 & C15 & C16 \\
\hline C01 & 1 & 1 & 1 & $\ldots$ & 1 & 1 & 1 & 2 & 2 \\
C02 & 1 & 1 & 3 & $\ldots$ & 2 & 2 & 3 & 4 & 4 \\
$\ldots$ & $\ldots$ & $\ldots$ & $\ldots$ & $\ldots$ & $\ldots$ & $\ldots$ & $\ldots$ & $\ldots$ & $\ldots$ \\
C14 & 1 & 0,333 & 1 & $\ldots$ & 0,333 & 0,333 & 1 & 2 & 2 \\
C15 & 0,5 & 0,25 & 0,5 & $\ldots$ & 0,333 & 0,333 & 0,5 & 1 & 1 \\
C16 & 0,5 & 0,25 & 0,5 & $\ldots$ & 0,333 & 0,333 & 0,5 & 1 & 1 \\
\hline Jumlah & 22,5 & 17,365 & 21 & $\ldots$ & 20,249 & 19,999 & 33 & 45 & 46 \\
\hline
\end{tabular}


Tabel 3. Matriks normalisasi untuk semua kriteria

\begin{tabular}{ccccccccccc}
\hline Kode & C01 & C02 & C03 & $\ldots$ & C13 & C14 & C15 & C16 & Bobot & CM \\
\hline C01 & 0,044 & 0,058 & 0,048 & $\ldots$ & 0,05 & 0,03 & 0,044 & 0,043 & 0,044 & 17,756 \\
C02 & 0,044 & 0,058 & 0,143 & $\ldots$ & 0,1 & 0,091 & 0,089 & 0,087 & 0,091 & 17,493 \\
$\ldots$ & $\ldots$ & $\ldots$ & $\ldots$ & $\ldots$ & $\ldots$ & $\ldots$ & $\ldots$ & $\ldots$ & $\ldots$ & $\ldots$ \\
C14 & 0,044 & 0,019 & 0,048 & $\ldots$ & 0,017 & 0,03 & 0,044 & 0,043 & 0,031 & 17,024 \\
C15 & 0,022 & 0,014 & 0,024 & $\ldots$ & 0,017 & 0,015 & 0,022 & 0,022 & 0,022 & 17,069 \\
C16 & 0,022 & 0,014 & 0,024 & $\ldots$ & 0,017 & 0,015 & 0,022 & 0,022 & 0,021 & 17,136 \\
\hline
\end{tabular}

Tabel 4. Nilai hasil matriks Fuzzy AHP perbandingan berpasangan antar kriteria

\begin{tabular}{|c|c|c|c|c|c|c|c|c|c|c|c|c|c|c|c|c|}
\hline & \multicolumn{4}{|l|}{ C01 } & \multicolumn{3}{|l|}{ C14 } & \multicolumn{3}{|l|}{ C15 } & \multicolumn{3}{|c|}{ C16 } & \multicolumn{3}{|c|}{ Jumlah Baris } \\
\hline & $\mathbf{L}$ & M & $\mathbf{U}$ & $\ldots$ & L & M & $\mathbf{U}$ & L & M & $\mathbf{U}$ & L & $\mathbf{M}$ & $\mathbf{U}$ & L & M & $\mathbf{U}$ \\
\hline $\mathrm{C} 01$ & 1 & 1 & 1 & $\ldots$ & 1 & 1 & 1 & 0,5 & 1 & 1,5 & 0,5 & 1 & 1,5 & 12,50 & 14,67 & 17,50 \\
\hline $\mathrm{C} 02$ & 1 & 1 & 1 & $\ldots$ & 1 & 1,5 & 2 & 1,5 & 2 & 2,5 & 1,5 & 2 & 2,5 & 15,00 & 20,67 & 27,00 \\
\hline$\ldots$ & $\ldots$ & $\ldots$ & $\ldots$ & $\ldots$ & $\ldots$ & $\ldots$ & $\ldots$ & $\ldots$ & $\ldots$ & $\ldots$ & $\ldots$ & $\ldots$ & $\ldots$ & & & \\
\hline C14 & 1 & 1 & 1 & $\ldots$ & 1 & 1 & 1 & 0,5 & 1 & 1,5 & 0,5 & 1 & 1,5 & 10,80 & 13,00 & 16,33 \\
\hline C15 & 0,67 & 1 & 2 & $\ldots$ & 0,67 & 1 & 2 & 1 & 1 & 1 & 1 & 1 & 1 & 10,13 & 11,93 & 16,33 \\
\hline C16 & 0,67 & 1 & 2 & $\ldots$ & 0,67 & 1 & 2 & 1 & 1 & 1 & 1 & 1 & 1 & 9,80 & 11,93 & 17,33 \\
\hline & & & & & & & & & & & tal & $\mathrm{M}$ & $\mathrm{J}]=$ & 218,57 & 276,50 & 358,83 \\
\hline
\end{tabular}

Kemudian mencari nilai CI dengan menggunakan persamaan berikut:

$$
\mathrm{CI}=\frac{\mu \max -n}{n-1}
$$

Keterangan:

$\mu$ max $=$ Nilai rata-rata dari $\mathrm{CM}$

$n \quad=$ Jumlah kriteria atau ukuran matriks

$$
\mathrm{CI}=\frac{17,3095-16}{16-1}=\frac{1,3095}{15}=0,0873
$$

Setelah mendapatkan nilai CI dilanjutkan dengan mencari nilai $\mathrm{CR} . \mathrm{CR}=\mathrm{CI} /$ Random index (RI), dimana syarat konsistensi harus kecil dari $10 \%$ atau $\mathrm{CR} \leq 0,1$. Karena matriks terdiri dari 16 kriteria maka nilai RI = 1,59 (Saaty, 2007).

$\mathrm{CR}=0,0873 / 1,59$

$\mathrm{CR}=0,055$ (konsisten)

\section{Perhitungan Fuzzy AHP Untuk Semua Kriteria}

Langkah selanjutnya yaitu berdasarkan inputan pakar pada Tabel 2 kemudian dilanjutkan dengan menentukan matriks perbandingan berpasangan antar kriteria dari AHP ke Fuzzy AHP atau fuzzyfikasi skala AHP ke Fuzzy AHP sesuai dengan skala nilai fuzzy segitiga (Chang, 1996) yang disajikan pada Tabel 4.

\section{Menentukan Nilai Sintesis Fuzzy}

Langkah selanjutnya yaitu menghitung nilai sintesis fuzzy (Si), misalkan untuk menghitung $\mathrm{Si}$ dari C01:

$$
\begin{aligned}
& \text { Si C01 }=(12,50 \quad 14,6717,50) \times\left(\left(\frac{1}{358,83}\right),\right. \\
& \left.\left(\frac{1}{276,50}\right),\left(\frac{1}{218,57}\right)\right)=\left(\begin{array}{lll}
0,035 & 0,053 & 0,08
\end{array}\right)
\end{aligned}
$$

Hasil dari perhitungan Si untuk keseluruhan dapat dilihat pada Tabel 5.
Tabel 5. Hasil perhitungan nilai sintesis fuzzy untuk semua kriteria

\begin{tabular}{ccccccc}
\hline & \multicolumn{3}{c}{ Jumlah Baris } & \multicolumn{3}{c}{ Nilai Sintesis } \\
\cline { 2 - 7 } & $\mathbf{L}$ & $\mathbf{M}$ & $\mathbf{U}$ & $\mathbf{L}$ & $\mathbf{M}$ & $\mathbf{U}$ \\
\hline $\mathrm{C} 01$ & 12,5 & 14,667 & 17,5 & 0,035 & 0,053 & 0,08 \\
$\mathrm{C} 02$ & 15 & 20,667 & 27 & 0,042 & 0,075 & 0,124 \\
$\ldots$ & $\ldots$ & $\ldots$ & $\ldots$ & $\ldots$ & $\ldots$ & $\ldots$ \\
$\mathrm{C} 14$ & 10,8 & 13 & 16,333 & 0,03 & 0,047 & 0,075 \\
$\mathrm{C} 15$ & 10,1 & 11,933 & 16,333 & 0,028 & 0,043 & 0,075 \\
$\mathrm{C} 16$ & 9,8 & 11,933 & 17,333 & 0,027 & 0,043 & 0,079 \\
\hline
\end{tabular}

Menghitung nilai Vektor dan Defuzzyfikasi

Tahap selanjutnya adalah menentukan nilai vektor (V) dan nilai ordinat defuzzyfikasi (d') dari nilai Si untuk semua kriteria (Tabel 6). Berikut misalkan untuk menghitung d' dari C01 (kriteria temperatur).

$$
\begin{aligned}
\mathrm{VSiC} 01 \geq \mathrm{VSiC} 02 & =\frac{L_{2}-U_{1}}{\left(M_{1}-U_{1}\right)-\left(M_{2}-L_{2}\right)} \\
& =\frac{0,042-0,08}{(0,053-0,08)-(0,075-0,042)} \\
& =\frac{-0,038}{-0,027-0,033} \\
& =\frac{-0,038}{-0,06}=0,638
\end{aligned}
$$

Bobot Vector

Berdasarkan nilai d' pada semua kriteria, maka diperoleh nilai bobot vektor (W') untuk semua kriteria tersebut. Nilai W' dapat dilihat pada Tabel 7.

\section{Normalisasi Bobot}

Terakhir adalah melakukan normalisasi bobot (W) yang diperoleh dari perhitungan tiap elemen bobot vektor dibagi jumlah bobot vektor itu sendiri, jumlah bobot vektor $=11,117$. Hasil normalisasi bobot untuk semua kriteria yang diperoleh dapat dilihat pada Tabel 7. Selanjutnya langkah menghitung bobot AHP dan Fuzzy AHP untuk alternatif per kriteria dapat dihitung dengan cara yang sama, seperti langkah di atas. 
Tabel 6. Nilai vektor dan defuzzyfikasi kriteria temperatur

\begin{tabular}{ccccccc}
\hline & $\mathbf{a}=\mathbf{L}-\mathbf{U 1}$ & $\mathbf{b}=\mathbf{M 1}-\mathbf{U 1}$ & $\mathbf{c =} \mathbf{M}-\mathbf{L}$ & $\mathbf{d}=\mathbf{b}-\mathbf{c}$ & $\mathbf{e}=\mathbf{a} / \mathbf{d}$ & $\mathbf{d}^{\prime}$ \\
\hline $\mathrm{C} 01>\mathrm{C} 02$ & $-0,038$ & $-0,027$ & 0,033 & $-0,06$ & 0,638 & 0,638 \\
$\ldots$ & $\ldots$ & $\ldots$ & $\ldots$ & $\ldots$ & $\ldots$ & $\ldots$ \\
$\mathrm{C} 01>\mathrm{C} 04$ & $-0,044$ & $-0,027$ & 0,016 & $-0,043$ & 1,028 & 1 \\
$\mathrm{C} 01>\mathrm{C} 15$ & $-0,052$ & $-0,027$ & 0,015 & $-0,042$ & 1,236 & 1 \\
$\mathrm{C} 01>\mathrm{C} 16$ & $-0,053$ & $-0,027$ & 0,016 & $-0,043$ & 1,231 & 1 \\
\hline $\mathrm{MIN}: 0,524$ & \multicolumn{7}{r}{}
\end{tabular}

Tabel 7. Normalisasi bobot vektor kriteria

\begin{tabular}{ccc}
\hline Kriteria & $\mathbf{W}^{\prime}$ & $\mathbf{W}$ \\
\hline $\mathrm{C} 01$ & 0,524 & 0,047 \\
$\mathrm{C} 02$ & 0,901 & 0,081 \\
$\ldots$ & $\ldots$ & $\ldots, 039$ \\
$\mathrm{C} 14$ & 0,435 & 0,039 \\
$\mathrm{C} 15$ & 0,41 & 0,037 \\
$\mathrm{C} 16$ & 0,447 & 0,04 \\
\hline
\end{tabular}

\section{Perhitungan Ranking}

Setelah menghitung semua alternatif per kriteria dan mendapatkan bobot akhir global tiap alternatif per kriterianya maka bobot alternatif tersebut dikalikan dengan bobot akhir global kriteria dengan cara perkalian matriks untuk menghasilkan hasil bobot akhir keseluruhan dan mendapatkan ranking dengan hasil bobot akhir yang tertinggi.

Dari data di atas tanaman pangan jagung mempunyai nilai tertinggi berdasarkan perhitungan yang telah dilakukan menggunakan metode Fuzzy AHP.

\section{Model Kelas Kesesuaian Lahan Menggunakan FIS}

\section{Pembentukan Himpunan Fuzzy}

Pemilihan himpunan fuzzy dan domain dari masing-masing himpunan ditentukan berdasarkan pengamatan dan pengelompokkan pola nilai masingmasing parameter yang terdapat pada buku petunjuk teknis evaluasi lahan untuk komoditas pertanian (2011) dan wawancara dengan pakar.

\section{Fungsi Keanggotaan}

Fungsi keanggotaan merupakan suatu kurva yang menunjukkan pemetaan titik-titik input data ke dalam nilai keanggotaannya yang memiliki interval antara 0 sampai 1 (Kusumadewi dan Guswaludin, 2005). Fungsi keanggotaan yang digunakan adalah fungsi trapezium.

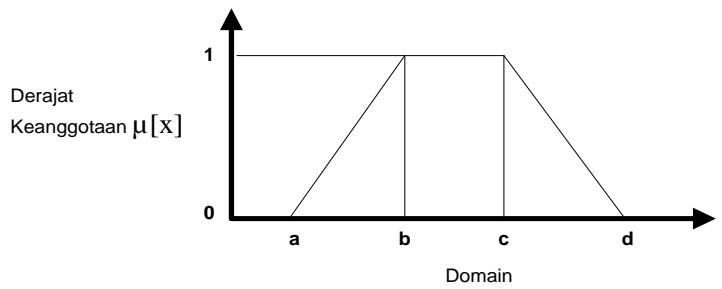

Gambar 4. Kurva trapezium
Fungsi Keanggotaan:

$$
\mu[x]=\left\{\begin{array}{cc}
0 ; & x \leq \text { a atau } x \geq d \\
(x-a) /(b-a) ; & a \leq x \leq b \\
1 ; & b \leq x \leq c \\
(d-x) /(d-c) ; & c \leq x \leq d
\end{array}\right.
$$

Misalnya untuk menghitung nilai input untuk variabel temperatur, curah hujan dan kelembaban berdasarkan nilai bobot alternatif satu yaitu Desa Ian Tena.

\section{Temperatur}

$\mu$ Tem_SangatSesuai $[23,75$ 24,25 28,75 29,25]

$\mathrm{f}(29)=\frac{d-x}{d-c}=\frac{29,25-29}{29,25-28,75}=\frac{0,25}{0,5}=0,5$

$\mu$ Tem_SesuaiBatasAtas [28,75 29,25 31,75 32,25]

$\mathrm{f}(29)=\frac{x-a}{b-a}=\frac{29-28,75}{29,25-28,75}=\frac{0,25}{0,5}=0,5$

\section{Curah Hujan}

$\mu$ Ch_Cukup Sesuai Batas Atas [899,75 900,25 $1199,751200,25]$

$\mathrm{f}(956,2)=1$

Kelembaban

$\mu \mathrm{K} 1 \_$SangatSesuai [32,75 33,25 89,75 90,25]

$\mathrm{f}(80)=1$

\section{Basis Aturan}

Pada metode mamdani fungsi implikasi yang di gunakan adalah Min, bentuk umum dari aturan yang digunakan dalam fungsi implikasi adalah: IF THEN, dengan operator fungsi implikasi yang digunakan yaitu AND (Khalyasmaa dan Zinovieva, 2017). Aturan pada basis aturan dibuat berdasarkan pendapat pakar. Pada penelitian ini, terdapat 16 parameter yang dikategorikan kedalam 5 kelompok parameter. Jumlah aturan pada basis aturan dalam penelitian ini sebanyak 622 aturan. Berikut misalkan untuk menghitung fungsi implikasi untuk kelompok parameter temperatur dan ketersedian air dari alternatif satu yaitu Desa Ian Tena. 
Tabel 8. Bobot akhir global tiap alternatif per kriteria

\begin{tabular}{lllllllllll}
\hline & C01 & C02 & $\ldots$ & C10 & C11 & C12 & C13 & C14 & C15 & C16 \\
\hline A01 & 0,333 & 0,333 & $\ldots$ & 0,333 & 0,333 & 0,333 & 0,333 & 0,241 & 0,333 & 0,333 \\
A02 & 0,333 & 0,333 & $\ldots$ & 0,333 & 0,333 & 0,333 & 0,333 & 0,272 & 0,333 & 0,333 \\
A03 & 0,333 & 0,333 & $\ldots$ & 0,333 & 0,333 & 0,333 & 0,333 & 0,487 & 0,333 & 0,333 \\
\hline
\end{tabular}

Tabel 9. Bobot akhir global kriteria

\begin{tabular}{lllllllllll}
\hline C01 & C02 & $\ldots$ & C09 & C10 & C11 & C12 & C13 & C14 & C15 & C16 \\
\hline 0,047 & 0,081 & $\ldots$ & 0,085 & 0,09 & 0,09 & 0,072 & 0,069 & 0,039 & 0,037 & 0,04 \\
\hline
\end{tabular}

Tabel 10. Hasil ranking alternatif tanaman pangan

\begin{tabular}{llcc}
\hline No & Nama & Hasil Bobot Akhir & Ranking \\
\hline 1 & Padi sawah tada hujan & 0,33 & 3 \\
2 & Padi gogo & 0,331 & 2 \\
3 & Jagung & 0,339 & 1 \\
\hline
\end{tabular}

[R1] IF Temperatur=Sangat sesuai AND Curah Hujan=Cukup sesuai batas atas AND Kelembaban=Sangat sesuai THEN Keluaran $=\mathrm{S} 2$ $\alpha 1=\operatorname{Min} \quad(\mu$ Tem_SangatSesuai $[0,5]$, $\mu \mathrm{CH}$ _CukupSesuaiBatasAtas $\mu \mathrm{KL} \_$SangatSesuai [1]) $=0,5$

[R2] IF Temperatur=Cukup sesuai batas atas AND Curah Hujan=Cukup sesuai batas atas $A N D$ Kelembaban=Sangat sesuai THEN Keluaran $=$ S2 $\alpha 2=\operatorname{Min}(\mu$ Tem_SesuaiBatasAtas [0,5], $\mu \mathrm{CH}$ _CukupSesuaiBatasAtas $\mu \mathrm{KL} \_$SangatSesuai [1] $)=0,5$

\section{Komposisi Aturan}

Dalam penelitian ini, komposisi aturan menggunakan metode Max, pada metode ini solusi himpunan fuzzy diperoleh dengan cara mengambil nilai maximum aturan. Berikut ini adalah contoh untuk komposisi aturan untuk aturan satu.

$$
\begin{aligned}
& \frac{a 1-69,75}{80-69,75}=0,5 \\
& \frac{90,25-a 2}{90,25-80}=0,5 \\
& a 1=0,5(80-69,75)+69,75 \\
& a 2=90,25-0,5(90,25-80) \\
& a 1=5,125+69,75=74,875 \\
& a 2=90,25-5,125=85,125
\end{aligned}
$$

Dikarenakan menggunakan metode Max maka nilai yang diambil adalah nilai terbesar. Berikut adalah fungsi yang dapat digambarkan dari aturan satu:

$$
\mu[x]=\left\{\begin{array}{cc}
0 ; & x \leq 74,875 \\
(x-69,75) /(80-69,75) ; & 69,75 \leq x \leq 74,875 \\
0,5 ; & 74,875 \leq x \leq 85,125 \\
(90,25-x) /(90,25-80) ; & 85,125 \geq 90,25
\end{array}\right.
$$

\section{Defuzzyfikasi}

Input dari proses defuzzyfikasi adalah suatu himpunan fuzzy yang diperoleh dari komposisi aturan-aturan fuzzy, sedangkan output yang dihasilkan merupakan suatu bilangan pada domain himpunan fuzzy tersebut. Sehingga jika diberikan suatu himpunan fuzzy dalam range tertentu, maka harus dapat diambil suatu nilai crips sebagai output. Dalam penelitian ini defuzzyfikasi menggunakan metode centroid of area, pada metode ini solusi crips diperoleh dengan cara mengambil titik pusat daerah fuzzy. Berikut ini adalah contoh hasil defuzzyfikasi untuk alternatif satu yaitu Desa Ian Tena.

$$
Z=\frac{(0,5 \times 80)+(1 \times 60)+(1 \times 80)}{0,5+1+1}=72
$$

Tabel 11 menyajikan nilai dan rangking hasil perhitungan untuk kesesuaian lahan menggunakan metode FIS berdasarkan nilai bobot alternatif untuk delapan desa yang dikaji.

Tabel 11. Hasil alternatif desa

\begin{tabular}{cclc}
\hline Rank & Kode & Nama Alternatif & Total \\
\hline 1 & A07 & Desa Kopong & 81 \\
2 & A04 & Desa Geliting & 81 \\
3 & A05 & Desa Namangkewa & 77 \\
4 & A06 & Desa Waiara & 74 \\
5 & A02 & Desa Umagera & 74 \\
6 & A08 & Desa Seusina & 74 \\
7 & A03 & Desa Wairkoja & 74 \\
8 & A01 & Desa Ian Tena & 72 \\
\hline
\end{tabular}

\section{Implementasi}

Dalam penelitian ini menerapkan Unified Modeling Language (UML) untuk analisis perancangan perangkat lunak, yang mana terdiri dari beberapa diagram yang digunakan, seperti: Usecase Diagram, Class Diagram dan Activity Diagram. Sistem yang dibangun merupakan sistem 
berbasiskan web dengan bahasa pemrograman PHP dan DBMS yang digunakan yaitu Mysql.

\section{Analisis Perancangan Perangkat Lunak}

Perancangan sistem dilakukan untuk mengetahui kebutuhan sistem, serta alur kerja dari sistem yang akan dibuat sehingga memberikan informasi yang baik mengenai sistem yang dibangun dengan menggunakan bahasa pemodelan UML. Usecase Diagram dari SPKC kesesuaian lahan yang dibangun dapat dilihat pada Gambar 5.

\section{Pengembangan Sistem}

SPKC kesesuaian lahan dengan jenis tanaman pangan ini merupakan sistem berbasis web yang dibangun dengan bahasa pemrograman PHP dengan DBMS yang digunakan yaitu Mysql. Tampilan dari halaman utama, tampilan halaman hasil perhitungan Fuzzy AHP dan hasil perhitungan FIS, dalam SPKC kesesuaian lahan yang dibangun dapat dilihat pada gambar berikut:

\section{Halaman Utama}

Ketika program dijalankan, pengguna akan memasuki halaman utama sistem yang dapat dilihat pada Gambar 6, sebagai pengantar kepada subsistem-subsistem lain dalam sistem yang dibangun. Terdapat dua subsistem yaitu subsistem model prioritas alternatif tanaman pangan dan subsistem model prioritas kelas kesesuaian lahan.

\section{Halaman Perhitungan}

Halaman perhitungan menampilkan nilai dan rangking alternatif tanaman pangan terbaik berdasarkan hasil hitung menggunakan metode Fuzzy AHP dan menampilkan nilai dan rangking alternatif lahan yang dikaji berdasarkan hasil hitung menggunakan metode FIS. Tampilan halaman hasil perhitungan FuzzyAHP dapat dilihat pada Gambar 7 dan hasil perhitungan FIS pada Gambar 8.

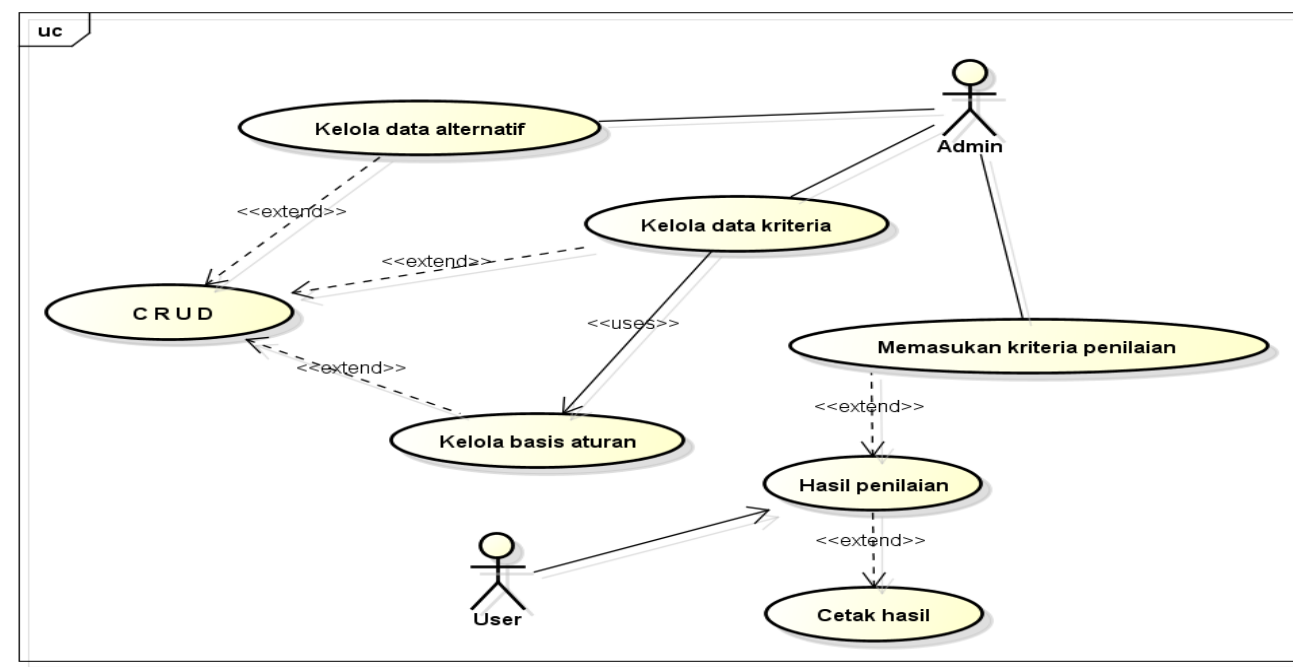

Gambar 5. Usecase diagram SPKC kesesuaian lahan

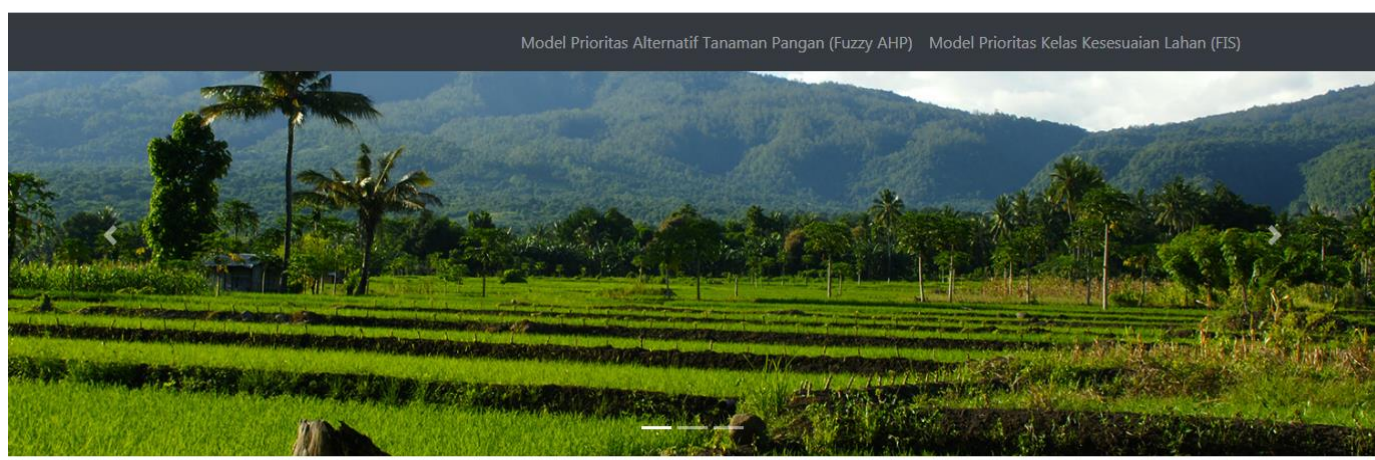

Sistem Pendukung Keputusan Cerdas

Sistem pendukung keputusan cerdas kesesuaian lahan ini merupakan sistem komputer interaktif menggunakan data, model, dan pengetahuan kepakaran dengan menggabungkan teknik artificial intelligent, agar dapat membantu dalam pengambilan keputusan untuk pemilihan alternatif tanaman pangan yang terbaik dengan lahan yang sesuai. Sistem ini menerapkan Fuzzy AHP untuk mendapatkan nilai prioritas alternatif tanaman pangan dan menggunakan Fuzzy Inference System untuk mendapatkan nilai prioritas kelas kesesuaian lahan.

Gambar 6. Halaman menu utama 


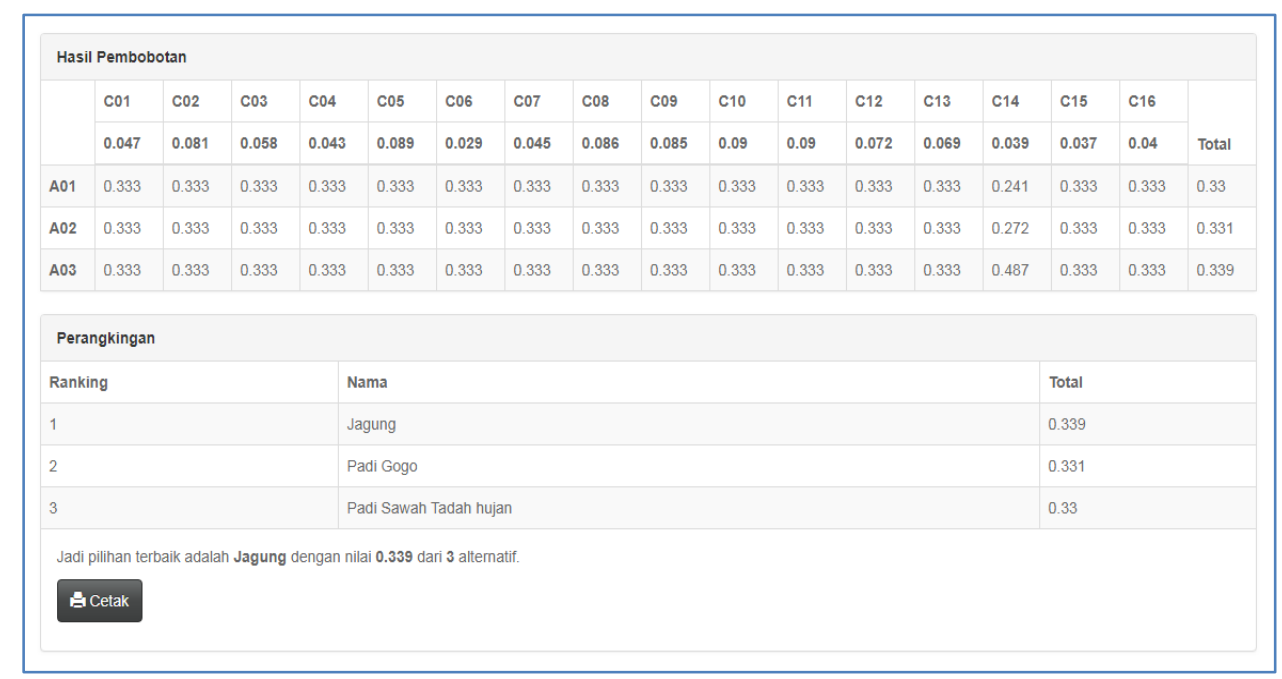

Gambar 7. Halaman hasil perhitungan Fuzzy AHP

\begin{tabular}{|c|c|c|c|}
\hline \multicolumn{4}{|c|}{ Hasil Defuzifikasi } \\
\hline Rank & Kode & Nama & Total \\
\hline 1 & A07 & Desa Kopong & 81 \\
\hline 2 & A04 & Desa Geliting & 81 \\
\hline 3 & A05 & Desa Namangkewa & 77 \\
\hline 4 & A06 & Desa Waiara & 74 \\
\hline 5 & A02 & Desa Umagera & 74 \\
\hline 6 & A08 & Desa Seusina & 74 \\
\hline 7 & A03 & Desa Wairkoja & 74 \\
\hline 8 & A01 & Desa lan Tena & 72 \\
\hline
\end{tabular}

Gambar 8. Halaman hasil perhitungan FIS

\section{Pengujian Sistem}

Terdapat dua pengujian sistem di dalam penelitian ini, yaitu: pengujian fitur sistem dan pengujian kompatibilitas terhadap perangkat keras dan sistem operasi. Pengujian fitur sistem dalam penelitian ini menggunakan Black Box Testing, yang mana pengujian yang dilakukan hanya mengamati hasil eksekusi melalui data uji dan cek fungsional perangkat lunak, tujuan dari Black Box Testing yaitu untuk mencari kesalahan atau kegagalan dalam operasi tingkat tinggi, yang mencakup kemampuan dari perangkat lunak. Pengujian kompatibilitas terhadap perangkat keras dan sistem operasi dilakukan untuk mengetahui keberhasilan dan kekurangan sistem serta penyebab kegagalannya maka perlu dilakukan uji coba program. Kesimpulan yang dapat diambil dari pengujian sistem yaitu program dapat berjalan dengan baik dan terjadi koneksi yang baik antara aplikasi dengan databasenya.

\section{KESIMPULAN DAN SARAN}

\section{Kesimpulan}

Penelitian yang telah dilakukan ini berhasil membangun suatu SPKC kesesuaian lahan yang menggabungkan metode Fuzzy AHP dan metode FIS untuk pemilihan alternatif tanaman pangan yang terbaik dengan lahan yang sesuai. Dari hasil dan pembahasan di atas, dapat disimpulkan bahwa dengan menggunakan metode Fuzzy AHP berdasarkan kriteria yang digunakan maka diperoleh hasil bahwa tanaman pangan jagung merupakan alternatif tanaman pangan terbaik dengan nilai 0,339 dari tiga alternatif tanaman pangan yang dikaji. Kemudian dengan menggunakan metode FIS berdasarkan kriteria yang digunakan dengan inputan nilai bobot alternatif dari delapan desa yang dikaji maka diperoleh hasil bahwa Desa Kopong dan Desa Geliting merupakan desa terbaik dengan nilai kesesuaian lahan 81 . 
Saran

Penelitian ini dapat dikembangkan ke berbagai komoditas tanaman dengan melakukan modifikasi pada parameter yang berupa peubah atau kriteria, dengan masukan model dan metode yang digunakan dapat dikombinasikan berdasarkan keperluan penelitian.

\section{DAFTAR PUSTAKA}

Aikhuele OD dan Turan MF. 2017. A subjective and objective fuzzy-based analytical hierarchy process model for prioritization of lean product development practices. Journal Management Science Letters. (7): 297-310.

[Badan Pusat Statistik] BPS Kabupaten Sikka. 2017. Sikka Dalam Angka 2017. Sikka: BPS Kabupaten Sikka.

Chang DY. 1996. Application of the extent analysis method on fuzzy AHP. Journal Operations Research. 95:649-655.

Djaenuddin D, Marwan H, Subagyo H, Hidayat A. 2011. Petunjuk Teknis Evaluasi Lahan Untuk Komoditas Pertanian. Bogor: Balai Besar Litbang Sumberdaya Lahan Pertanian Badan Litbang Pertanian Departemen Pertanian.

Fibrian CD, Martini S, dan Marimin. 2010. Sistem penunjang keputusan untuk optimalisasi pemanfaatan limbah padat kelapa sawit. Jurnal Teknologi Industri Pertanian. 20(2):130-142.

Hendra, Herdiyeni Y, dan Marimin. 2014. Sistem pendukung keputusan cerdas pengembangan agroindustri karet alam dengan pendekatan produktivitas hijau menggunakan fuzzy AHP. Jurnal Teknologi Industri Pertanian. 24(2):82-96.

Insani F. 2015. Pemodelan sistem pakar berbasis komputasi lunak untuk evaluasi kesesuaian lahan komoditas serealia: studi kasus kabupaten bogor. [Tesis]. Bogor: Institut Pertanian Bogor.
Khalyasmaa IA dan Zinovieva E. 2017. Intelligent decision support system for technical solutions efficiency assessment. Proceedings of 2017 IEEE $2^{\text {nd }}$ International Conference on Control in Technical Systems. St Petersburg, Rusia. 25-27 October 2017.

Kusumadewi S dan Guswaludin I. 2005. Fuzzy Multi-Criteria Decision Making. Yogyakarta: Graha Ilmu.

Navianti RD, Usadha RNGI, dan Widjajati AF. 2012. Penerapan fuzzy inference system pada prediksi curah hujan di Surabaya Utara. Jurnal Sains dan Seni. 1(1): 23-28.

Marimin dan Maghfiroh N. 2010. Aplikasi Teknik Pengambilan Keputusuan dalam Manajemen Rantai Pasok. Bogor: Institut Pertanian Bogor.

Marimin, Adhi W, dan Darmawan AM. 2017. Decision support system for natural rubber supply chain management performance measurement: a sustainable balanced scorecard approach. Journal Sup Chain Mgt. 6(2):49-59.

Saaty TL. 2007. On the Invalidity of Fuzzifying Numerical Judgments in the Analytic Hierarchy Process. Journal Mathematical and Computer Modelling. 46:62-75.

Sevani N, Marimin, dan Sukoco H. 2009. Sistem pakar penentuan kesesuaian lahan berdasarkan faktor penghambat terbesar untuk tanaman pangan. Jurnal Informatika. 10(1):23-31.

Taiyeb. 2017. Evaluasi Kesesuaian Lahan Untuk Tanaman Kemiri Pada Sistem Lahan Salo Saluwan Di Kota Palu. Journal Forest Sains. 14(2): 98-107.

Wren GP, Mora M, Forgionne G, Gupta J. 2009. An integrative evaluation framework for intelligent decision support systems. Journal Operations Research. 195: 642652. 